\title{
The State of Coos County: Local Perspectives on Community and Change
}

\author{
BYCHRIS R. COLOCOUSIS
}

\section{Background}

$\mathrm{H}$

EAVILY FOREsTed Coos County is the least popu-

lated and northernmost county in New Hamp-

shire. The southern part of the county contains

portions of the White Mountain National Forest, including 6,288-foot Mount Washington, and other major tourist destinations relatively accessible to population concentrations to the south. Northern Coos is closer to Montreal than to the urban areas of southern New Hampshire. Here the terrain transitions from rugged mountains to the rolling hills and flat agricultural plains of southern Quebec. With ample natural amenities including mountains, forests, and rivers, Coos affords numerous recreational opportunities to residents and visitors, from winter skiing and snowmobiling to hiking, fishing, and kayaking in the summer. The county's largest population center is the former papermaking city of Berlin, with about 10,000 residents.

Coos is also a working county. With abundant timber and powerful rivers, it has long been a major producer of wood products, especially pulp and paper. In recent years, it has been hard-hit by job losses as forest products and other manufacturing industries contract. From 1969 to 2005, the percentage of all county jobs in manufacturing declined from 34 to 10 percent. ${ }^{1}$ Job losses in the pulp and paper industry account for much of this trend. The percentage of total county earnings from pulp and paper mills declined from 36 percent in 1969 to 11 percent in 2005. ${ }^{2}$ During this period, employment in the service sector has seen a correspondingly large increase, though service-sector wages are often far lower than those in manufacturing. Since 2006, three pulp or paper mills in the county have shut down after years of periodic closures and layoffs, permanently eliminating more than 650 relatively high-paying jobs. ${ }^{3}$ Today only one operating paper mill remains, with yet another round of layoffs looming.

These latest closings and job losses contribute to demographic changes that the county has experienced over the past several decades. In contrast to the rest of New Hampshire, the county lost population steadily from its height in 1940 to 2000, with the exception of a brief increase in the 1970s. Since 2000, population change has hovered around zero, with a slight downward trend evident from 2005 to 2006. ${ }^{4}$ However, stagnant population trends mask substantial in- and out-migration in recent years; during the 1990s the number of fifty-somethings grew while the county lost large numbers of people in their late teens and twenties.

\section{Current Conditions}

By 2006, Coos had 33,007 residents, 16 percent fewer than in 1940. Much of the loss in Coos has been due to the on-going out-migration of young adults. Between 1990 and 2000, the county lost nearly 40 percent of its $20-29$ year olds. This protracted young adult out-migration has left few young families having children and many older adults. As a result, Coos had more deaths than births between 1990 and 2006. One bright spot in its demographic profile is a recent influx of adults in their 50s, a trend consistent with that in other recreational counties in the country that attract amenity migrants. Residents of Coos have long benefited from the proximity of abundant natural resources; with the pulp and paper industry waning and recreation on the rise, the county's unique location amid mountains, streams, and forests likely will continue to serve it well, albeit in different ways.

The region is at a crossroads. The traditional economic base of the county is disappearing, and it is yet to be determined what industry, or mix of industries, will replace it. Dynamic tensions exist between traditional forms of economic activity and resource use, and emerging community development strategies that are premised on the attractiveness of the place and, implicitly or explicitly, the importance of environmental stewardship and resource conservation. Communities across the county are charged with reinventing themselves economically. Concerns about 
Figure 1: NeWCOMERS VS. LONG-TIMERS

\section{Question:}

Have you always lived in this area?

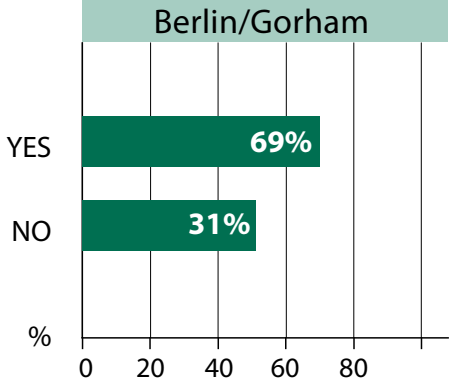

the economic future of the region are particularly evident in Berlin, where decades of demographic and economic decline have lead to passionate public discussions comparing the merits of traditional forest-based industries, newer development strategies such as prisons and casinos, and development predicated on the recreational amenities of the rural area. The now inactive mill complex in the center of the city is often at the heart of these discussions.

Coos County is not alone in this transition. In many places, rural America is changing dramatically under pressures from globalization, demographic shifts including new migration patterns, and environmental transformations. Broadly speaking, three sets of dynamics are reshaping rural places. Some attractive, "amenity-rich" rural areas are growing as baby boomers move there to retire, and as "footloose professionals" choose to settle in smaller communities. Other places, long dependent on resources such as timber or agriculture, are now losing population as employment in these traditional industries declines. Finally, a third type consists of chronically poor rural communities where decades of under investment have left a legacy of deep poverty and weakened community institutions. Rural America consists of different kinds of places, heading into the future along different paths. Coos today primarily represents a mixture of the first two types, though poverty and economic disadvantage more generally are also concerns.

\section{The Carsey Survey: Tracking Change}

To learn more about how Coos County residents view the changes happening in their communities and the region, the Carsey Institute conducted telephone interviews with more than 1,700 adults in Coos and adjacent Oxford County, Maine in spring and summer 2007. Through about 100 survey questions researchers collected data on residents' experiences of change, their levels of concern about environmental issues, and the key issues they feel their
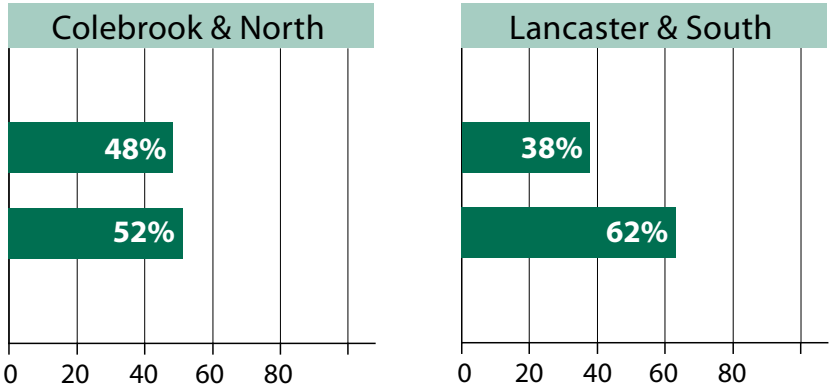

communities are facing. This information is especially timely given the present point of transition in Coos. The survey also provides data on the economic and demographic characteristics of the county population, such as marital status, educational attainment, race/ethnicity, age, politics, and household income. The survey data can be used to examine the relationships between demographic factors, and to compare the changing circumstances of subgroups such as newcomers versus long-timers, or low-income versus middle-income and affluent residents. The survey presents a useful opportunity to track change in ways that go beyond the limitations of commonly-used secondary data, and offers a benchmark against which future changes can be measured and assessed.

Below is a brief discussion of the survey findings. While the results for Coos are discussed at length throughout the report, the figures that display data for Coos as a whole also show data from Oxford County, Maine for purposes of comparison. These comparisons will be more meaningful in the future, when Oxford will function as a "control" county against which change in Coos can be compared, particularly as it relates to new investments, initiatives, and choices made by Coos residents. Where relevant, the Coos population is separated into subgroups according to length of residence, income, and age..$^{5}$

While county-level trends and conditions can provide an informative overall picture, they mask substantial variation from place to place across the county. To understand these differences, respondents were grouped according to where they live: Berlin/Gorham; Lancaster and southern Coos; and Colebrook and northern Coos. ${ }^{6}$ The differences between communities outlined below reflect real variation in conditions, but also in the perspectives of those living in each place. While half of Coos residents have moved to the county as adults, this is not true of all places in the county. For example, Lancaster and the rest of southern Coos have a greater percentage of people who moved to the area as adults, while the Berlin-Gorham area is notable for the relatively low percentage of newcomers living there.

Newcomers' perspectives can differ from those of longtime residents. In part, this is due to the higher average so- 
Figure 2: HOUSEHOLD INCOME DISTRIBUTION

Question:

What was your total household income (including all wages, public assistance and child support) for 2006, before taxes?

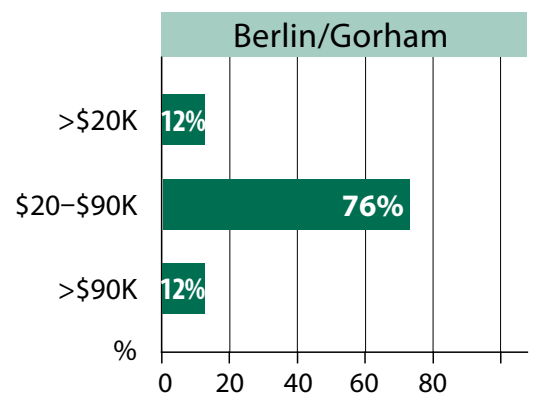

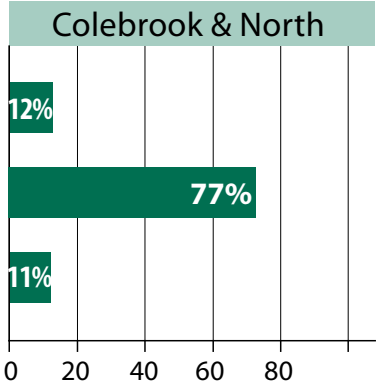

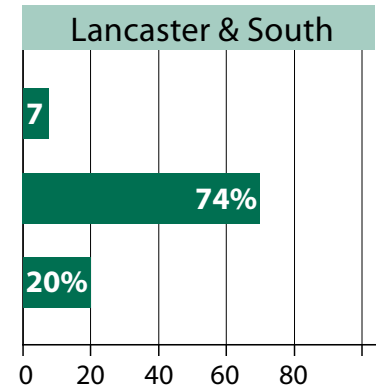

cioeconomic status of newcomers. They are more likely to be affluent than long-timers, with over 20 percent reporting household incomes greater than $\$ 90,000$, compared to 8 percent for long-timers. Newcomers are much more likely to be college graduates: 44 percent to 27 percent for long-timers. Looking at the county population by household income, similar trends emerge. Seventy percent of affluent residents moved to the county as adults, versus 45 percent of middle-income and 51 percent of low-income residents. Sixty-five percent of affluent residents have a college degree, versus only 35 percent of middle-income respondents, and 12 percent of low-income residents.

Differences in socioeconomic status between newcomers and long-timers become apparent when looking at household income by place. The southern part of the county has fewer lower-and lower-middle income families than Berlin/Gorham or the north, and more households with incomes above $\$ 90,000$. These differences in income reflect the geography of economic opportunity in the county as well as length of residence. The southern part of the county is less isolated, and has not been as severely affected by mill closings as have
Berlin, Gorham, Groveton, and places further north.

Levels of concern about local population decline are affected by the presence of newcomers. Concern is highest in Berlin/Gorham, and lowest in Lancaster and southern Coos. Whether people see population decline as a problem or not in their communities likely depends not only on population trends, but also on how long they have been around to witness decline firsthand. Berlin/ Gorham, with far fewer newcomers than other places in the county, declined in population by 16 percent from 1990 to 2006. By contrast, Lancaster and southern Coos grew by 3 percent, with most of that growth coming since 2000. In terms of the "three rurals" paradigm outlined above, Berlin/Gorham has much in common with declining resource-dependent places, while Lancaster and the south exhibit characteristics consistent with growing high-amenity places. More than 60 percent of residents in Lancaster and southern Coos saw a lack of affordable housing as an issue, while only 37 percent of Berlin/Gorham residents did.

\section{Figure 3: Community PROBLEMS}

QUESTION: Which of the following do you consider to be important problems facing your community today?

\section{CATEgories:}

Lack of recreational opportunities Violent or property crime Too-rapid development or sprawl Population declining as people move away Not enough health and social services Poverty or homelessness Schools not as good as they should be Lack of affordable housing Manufacture or sales of illegal drugs Lack of job opportunities
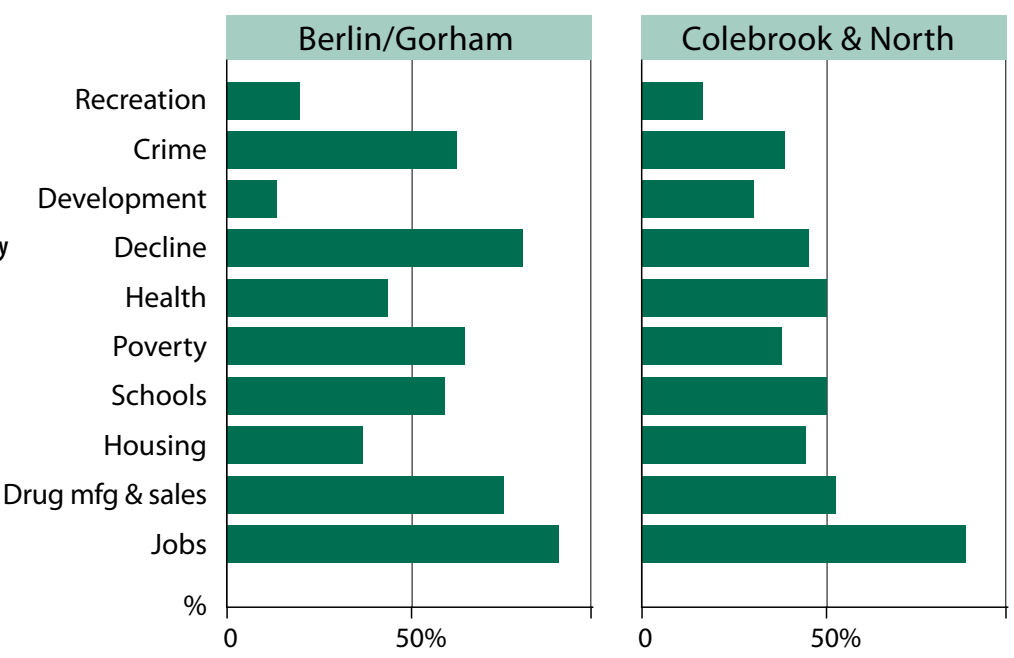

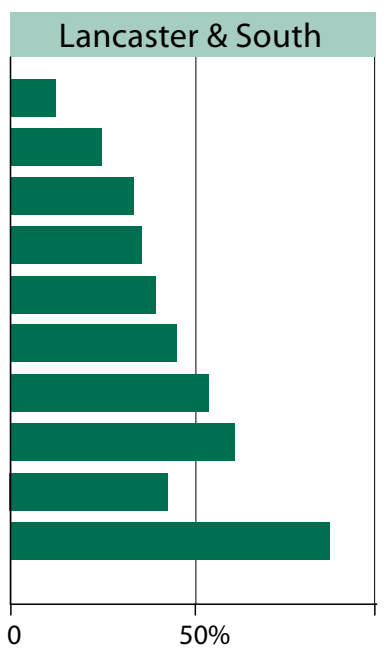


Figure 4: OUTLOOK ON FUTURE OF COMMUNITY

Question:

Based on what you see of the situation today, do you think that ten years from now, your community will be a better place to live, a worse place, or about the same?

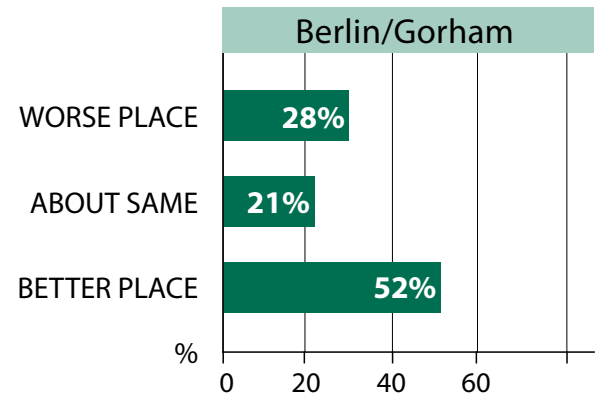

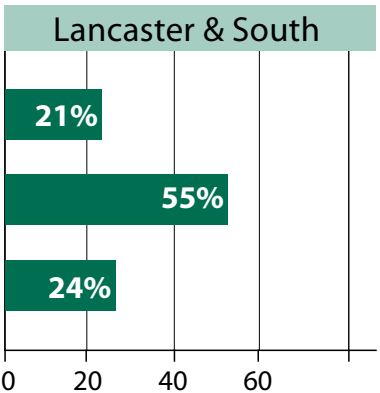

Just as economic and demographic circumstances vary by place, so do residents' concerns about community issues such as poverty, drugs, and crime. Berlin/Gorham, containing the only city and largest urbanized area in the county, stands out with respect to many of these issues. Sixty-four percent of Berlin/Gorham residents said that poverty and homelessness are problems in their community, compared to 46 percent in the south and 37 percent in the north. Concern about violent and property crime was highest in Berlin, where 75 percent of people said it is a problem. ${ }^{7}$ By contrast, 38 percent in the north and 25 percent in the south reported crime as a problem. Concern about drug sales and manufacturing was also highest in Berlin/Gorham (75 percent), and lower in the north (51 percent) and south (41 percent).

Differences in concern about community issues between nativity, income, and age groups reflect in part where these groups live across the county. Long-timers and low-income residents are more likely to live in and around Berlin; these groups are more concerned than newcomers or more affluent residents about crime. However, newcomers were as likely as long-timers to report poverty as a community problem. Affluent residents (69 percent) were the income group most likely to say that poor schools are a problem. Young people were the age group most concerned with crime (53 percent).
Fifty percent of those in the northern part of the county consider access to health and social services a problem. While this figure was lower in Berlin/Gorham and the southern part of the county, it is worth noting that over one-third of residents in each area saw service provision as deficient. Newcomers were more likely (48 percent) than long-timers to see a lack of health/social services as a problem; this may reflect differences in expectations of service provision between the two groups.

\section{Economic Change and Uncertainty about the Future}

A key theme that emerges from the survey data is that of uncertainty regarding the county's future, and divergent economic trajectories among its families. Just under onequarter of Coos residents think their community is heading in the wrong direction, while just over one-third have faith that their community will become a better place to live. Optimism about the future in Berlin/Gorham, which is coming to grips with the recent closure of a pulp mill, is double that of any other place in the county. Residents of Berlin/Gorham are clearly looking to the future with hope and an eye on new choices. But pessimism is higher there as well, reflecting the uncertainty facing the community.

Figure 5: RECENT FINANCIAL CHANGE

\section{QUESTION:}

Would you say that you and your family are worse off financially, about the same, or better off than you were 5 years ago?

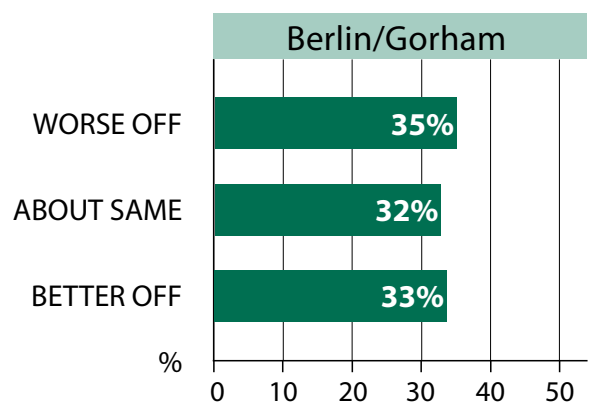

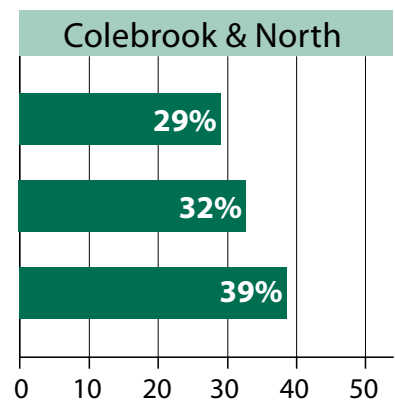

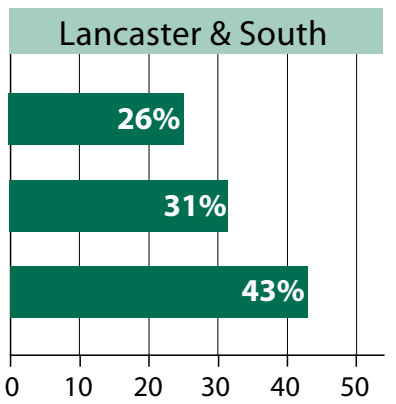


Figure 6: COMMUNity EFFECTS OF FOREST-BASED JOB LOSS

\section{Question:}

With regard to the place where you live, I'd like to know whether you think a loss of forestry jobs or income has had no effect, minor effects, or major effects on your family or community over the past 5 years?

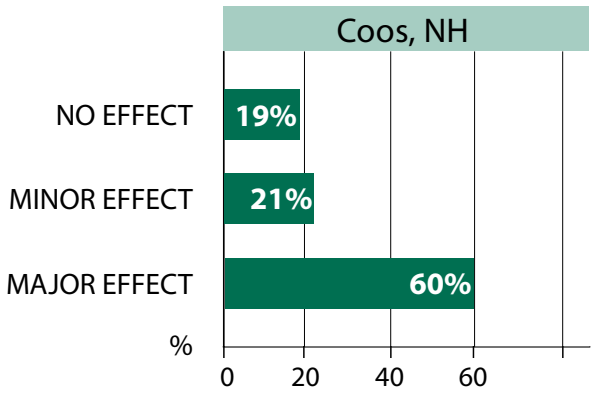

The northern and southern parts of the county are quite similar in terms of outlook on the future, with a majority in each seeing their community as being about the same in ten years. Long-timers (27 percent answering "worse") are slightly more pessimistic than newcomers (20 percent).

The county is split more evenly with respect to families' recent economic fortunes. Just under one-third of respondents said they and their families are worse off than they were five years ago, while just over one-third said their economic circumstances have improved in recent years. However, more low-income residents (42 percent) said they are worse off, compared to middle-income and affluent residents. At the other end of the income scale, two-thirds of affluent residents said they are better off. The middleincome population splits evenly into thirds with respect to their recent economic fortunes, suggesting the county's middle class may be feeling these changes most acutely. Berlin/Gorham has the highest percentage of residents doing worse, while Lancaster and the south have the greatest percentage who said they are better off.

\section{Economic Disruptions and Hardship}

These trends are closely linked to the economic disruptions the county is experiencing as the traditionally dominant industry, pulp and paper, continues to restructure. These survey data put these changes in historical perspective, and demonstrates the seismic shift in what people in the region do for work. At least a quarter of Coos respondents had a parent who worked in the mills or in a related, forest-based industry such as logging; this number underscores the historical centrality of work in the mills and woods to the livelihood and identity of the place. ${ }^{8}$ Today, 81 percent of Coos residents see the loss of forest-based jobs as having an impact on their communities; 60 percent say these community effects are major. But the consequences of mill closures and related job losses are not perceived the same way by all residents. Fewer newcomers saw the loss of forest-related jobs as an issue at all, and middle-income residents were most concerned with the loss of forest-related jobs.

FIgURE 7: RECENT ECONOMIC DISLOCATIONS AND PUBLIC ASSISTANCE RECEIPT

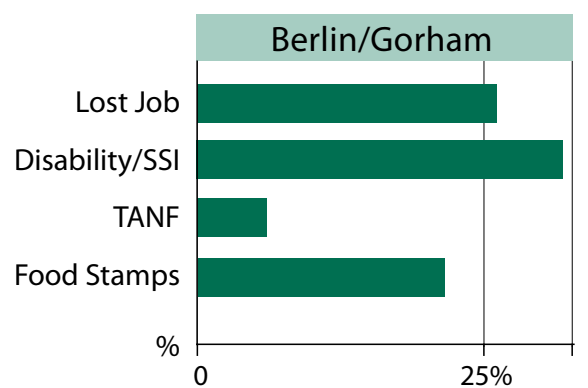

QUESTIONS:

During the last 7 calendar years, did you lose a job or leave one because your plant or company closed or moved, your position or shift was abolished, insufficient work, or some other similar reason?

Have you received any income from disability insurance or SSI within the past two years?
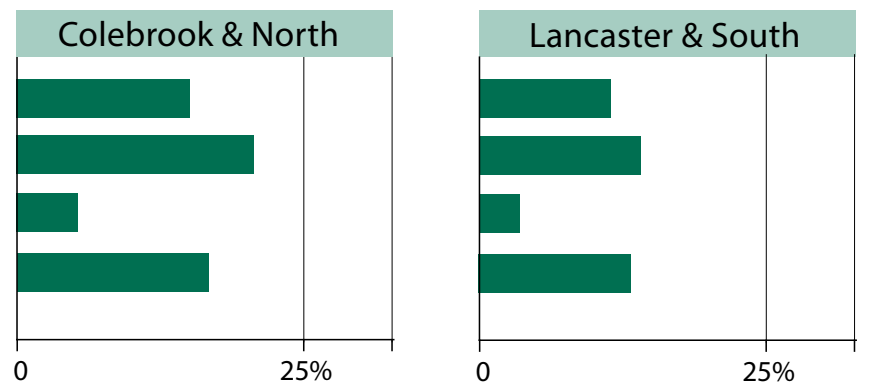

Have you received any from TANF (the "Temporary Assistance for Needy Families" program) within the past two years?

Have you received food stamps within the past two years? 
FIGURE 8: SECOND JOBS

\section{Question:}

In addition to the main job you just described, do you have another job or do other work to earn money?
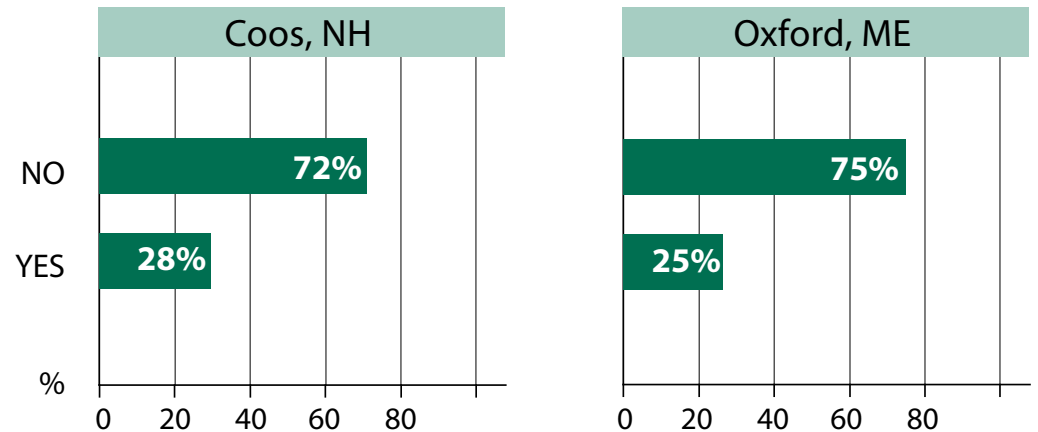

Many families have been directly affected by the elimination of these and other positions. Seventeen percent of Coos residents said they had lost a job for economic reasons in the past seven years. But economic dislocations have not hit the county uniformly from place to place. Twenty-six percent of people in Berlin/Gorham have recently lost a job due to a business closing or a position being eliminated. However, this figure was 11 percent in the southern part of the county, and 14 percent in the north. Long-timers were almost twice as likely as newcomers to have lost a job (21 percent to 12 percent). Twenty-one percent of middleincome residents said they recently lost a job, compared to 14 percent of low-income residents, and 10 percent of affluent residents. Here again, the impact of the changing forest products industry appears to be especially hard on the region's middle class.

The variation in difficult economic circumstances across the county is also evident in the extent to which people rely on public assistance programs. The percentage of people who received disability or SSI payments in the past two years was highest in Berlin/Gorham and lowest in the south.
The survey captured what many already know about employment patterns in the northernmost reaches of New Hampshire. People are hard-working, and over one-quarter report that they have a second job to make ends meet. While this figure reflects a strong work ethic, it also underscores the difficulty of making a living in Coos County. Thirty-one percent of middle-class residents reported having a second job, more than low-income or affluent residents. In many cases, these residents and their families are middle-income only because of the income provided by employment beyond their primary job. Indeed, of residents with household incomes between $\$ 20,000$ and $\$ 40,000,37$ percent said they have a second job; this is the highest figure for any income group. While many people in Coos have a second job, over 90 percent of residents said that a lack of job opportunities is a problem in their community.

Figure 9: Considerations In DECISION TO STAY IN AREA

\section{Question:}

Do the following things seem not important, somewhat important, or very important to you, when you think about whether you will stay here or move away in the future?

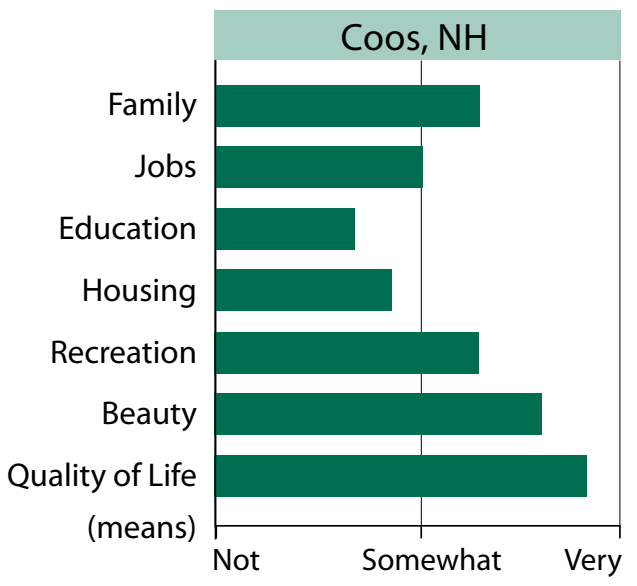

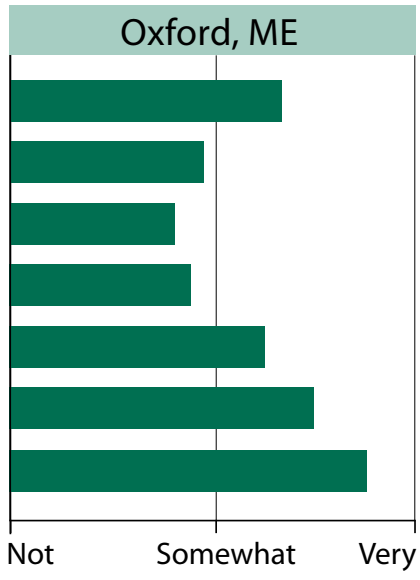




\section{Attachment to Place}

While the trends and conditions outlined above paint Coos County as a place in decline, the region also has much in common with other amenity-rich places. A consistent theme in the survey data is the lure of the area's natural amenities and quality of life. More than half of newcomers said that the area's natural beauty and quality of life were very important considerations in their decision to move to the area. More than two-thirds of residents surveyed said that these factors were very important in their choices about whether to stay or leave in the future. Proximity to family was another important consideration in decisions to stay or leave, while employment, educational, and housing opportunities were less important factors.

However, the area's natural beauty is not the only important consideration for those moving to the county. Over 40 percent of affluent newcomers said employment opportunities were very important in their decision to relocate to Coos, perhaps indicating opportunities for "footloose professionals" in the region. Affluent residents felt that ties to family were less important in decisions to stay or leave, compared to lower-and middle-income residents. Conversely, recreational opportunities were more important for affluent residents' decisions about staying or leaving. At the other end of the income scale, over one-third of low-income newcomers said that housing opportunities were very important in their decision to move to Coos, and half said getting away from city problems was very important.

Differences between groups are also apparent with respect to outdoor activities. Long-timers were more likely than newcomers to participate in hunting, camping, swimming, biking, and especially off-highway vehicle riding. About twice as many (18 percent) long-timers as newcomers expressed concern about a lack of recreational opportunities. This may reflect long-timers' experiences with decreasing access to land due to more lands being posted, or other reasons. However, it may also reflect different recreational preferences between the two groups. Low-income residents were least involved in all outdoor activities, particularly skiing and boating. In many cases, this reflects the substantial financial investment necessary to participate in such activities. They were also the income group most likely to perceive a lack of recreational opportunities as a problem in their communities. Importantly, young people were the age group most concerned with a lack of recreational opportunities.

\section{Limited Opportunity for Youth}

A solid majority of Coos residents would advise a teenager to leave their community for opportunities elsewhere. This is consistent with findings across rural America in other survey work, and likely reflects both the recognition of limited opportunities in rural areas and a cultural expectation that youth will broaden their horizons elsewhere, perhaps before returning home. ${ }^{9}$ These perceptions and expectations are shared by many young people in Coos; more than one-third of them said they planned on moving away in the next five years. Further, a greater percentage of young than mid-aged or older residents saw their communities becoming worse places to live in ten years.

\section{Figure 10: Advice to teens}

\section{Question:}

If your own teenage child, or the child of a close friend, asked you for advice, would you recommend that they should plan to stay in this town as an adult, or move away for opportunities somewhere else?
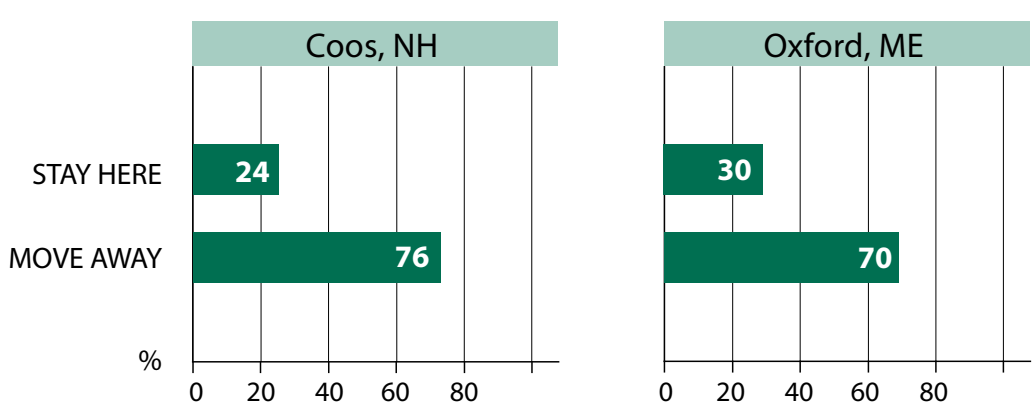
Figure 11: TRUST, SOCIAL COHESION, AND CONFIDENCE IN LOCAL GOVERNMENT
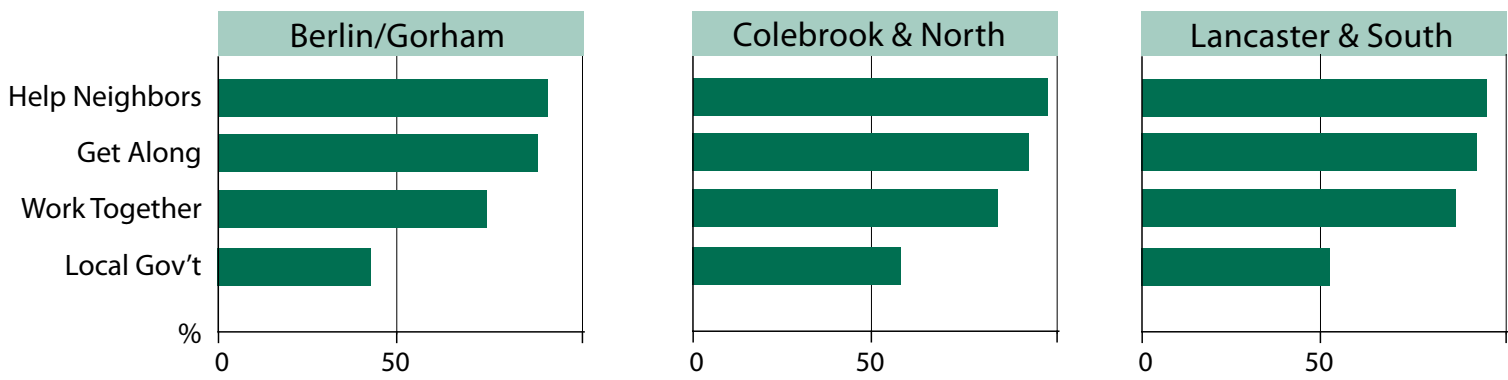

Question: Do you agree or disagree with the following statements about your community?

1. People around here are willing to help their neighbors.

2. People in this community generally trust one another and get along.

3. If this community were faced with a local issue such as the pollution of a river or the possible closure of a school, people here could be counted on to work together to address it.

4. Do you think that local government has the ability to deal effectively with important problems?

\section{Civic Culture and Community Issues}

While many Coos County residents recognize the limited opportunities that currently exist for young people in the region, the county's communities are rich in civic culture. More than 90 percent of Coos residents report that people in their community generally trust each other and get along, and that people are willing to help their neighbors. Slightly fewer agreed that people in their community can work together effectively to deal with local issues, but even so, over three quarters agree people can cooperate to solve problems. While the percentage reporting that people trust each other and get along increases with household income, it is above 85 percent for all three income groups. High levels of trust and social cohesion are the norm across much of rural America, with the exception of chronically poor places such as the Mississippi Delta and Central Appalachia. In these regions, fewer people agree with such statements about how well local people get along and work together.

Social cohesion is high across the county, but communities do differ with respect to residents' perceptions of how well they can work together. Just under three-quarters of Berlin/Gorham residents agreed that local people could work together effectively if they were faced with a local issue, while 88 percent of people in other places agreed they could. Furthermore, fewer residents of Berlin/Gorham compared with other places said that local government can effectively deal with local problems. Across the county, confidence in local government decreases as household income increases, with more lower-income residents agreeing that local government can effectively deal with problems. However, this difference may have more to do with less direct engagement with local government than with actual experiences of governmental effectiveness.

Levels of civic engagement are also high in Coos, with 58 percent of residents belonging to at least one local business, civic, government, or other type of organization. Affluent residents, newcomers, and older residents are more likely to be parts of such groups or organizations than their counterparts, with between 62 percent and 69 percent of each group reporting at least one form of membership. While rates of civic engagement are lower for low-income residents, almost half report membership in at least one local group. 
Figure 12: Community EnVironmental efFeCts

Question: Have these environmental issues had no effect, minor effects, or major effects on your family and community over the past 5 years?

ISSUES:

Water quality or supply problems

Conversion of farmland to other uses

Urban sprawl or rapid development of the countryside

Global warming or climate change Loss of forestry jobs or income
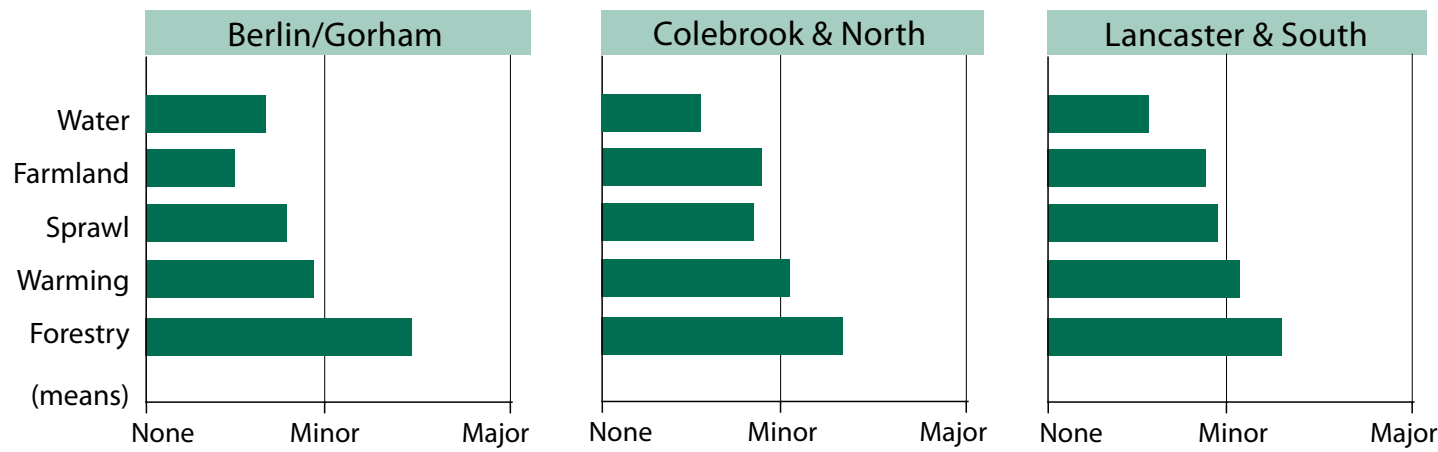

\section{Environmental Change and Natural Resources}

Perceptions of environmental change also differ from place to place across Coos. Places with more newcomers are more likely to be concerned about issues related to population growth. Only 13 percent of people saw sprawl as a problem in Berlin/Gorham, while 33 percent said it was a problem in Lancaster and the southern part of the county. Reported community effects of sprawl were greatest in the south, while the north and south reported similar community effects of the conversion of farmland to other uses. Seventy percent of people in the county said that climate change has had some effect on their communities; 32 percent said that these effects were major.

As the economy continues the transition away from traditional industries, Coos residents are confronting new resource use and management questions. A plurality of residents (41 percent) said that resources should be conserved for future generations, rather than used for job creation. However, more newcomers (44 percent) than long-timers (38 percent) favored conservation, while nearly twice as many long-timers (36 percent) than newcomers
(20 percent) said resources should be used for job creation. Three times as many long-timers (19 percent) as newcomers saw conservation rules as having negative effects on their communities. These differing perspectives likely stem from stronger ties to the traditional forest-based economy among long-timers.

As the region's economy undergoes deep structural change, new forms of resource use will emerge alongside an increasing focus on conservation. However, residents' perceptions of appropriate resource management approaches differ within and across communities. The percentage of residents who said that resources should be used for job creation was highest in Berlin/Gorham, a place with deep historical and contemporary ties to the pulp and paper industry, and where the need for new economic development is clearly in residents' minds. The percentage that favored conservation was highest in the southern part of the county, which is seeing new forms of economic growth related to natural amenities.

Figure 13: Perspectives on Resource use

\section{Question:}

For the future of your community, do you think it is more important to use natural resources to create jobs, or to conserve natural resources for future generations?

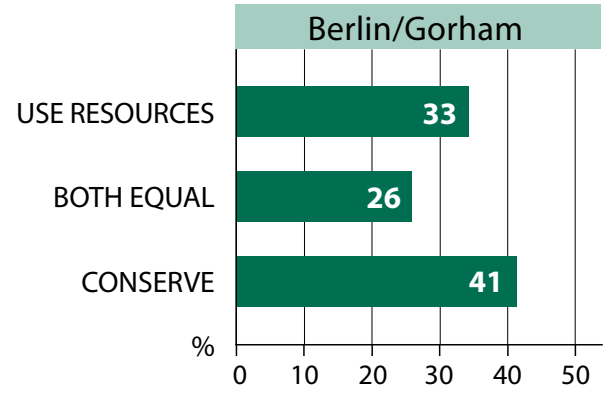

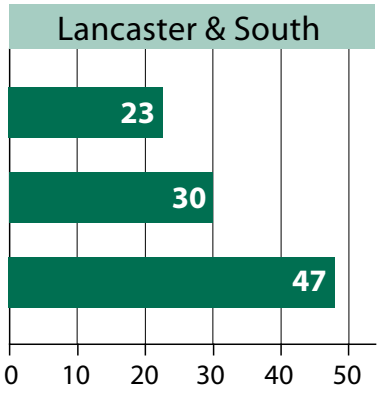




\section{New Challenges, New Opportunities}

While the varied demographic and economic dynamics that are reshaping Coos County can be identified, the ways in which these changes will play out are anything but clear. The southern part of the county is seeing some population growth and rising affluence for many households, while Berlin/Gorham and other communities in the north are seeing continued population loss and are adjusting to the decline of the region's pulp and paper industry. This mixture of forces, and the uncertainty they bring are evident in how the county's families are doing, and where they see their communities heading in the future. Middle-income families appear to be particularly hard hit by the changing economy. The county is split into thirds in terms of families' recent economic trajectories, and the state of middleincome families is particularly uncertain. Long-timers have been more strongly impacted than newcomers by the decline of the manufacturing sector in the region, and the perspectives of long-timers and newcomers can differ in important ways. Perspectives on the future of the county's communities are also mixed, and vary substantially from place to place.

Although the county has been hard-hit by economic restructuring, the survey suggests that residents appreciate the region's natural amenities and the trust and cooperation associated with small close-knit communities that both draw people to the region and make them want to stay. It is reasonable to assume that the future of the county will depend on capitalizing on that appreciation in creative new ways. Clearly, Coos County is at a turning point in its history, adjusting to dramatic economic changes, and preparing to chart a future course. The survey has captured how residents in 2007 were experiencing those changes, laying the baseline for future comparisons. When it is repeated in 2009 , analyses of any changes could be useful in building broader understanding of where the county is headed.

\section{Data Used In This Report}

The survey was administered by telephone to adults (18 years and older) in Coos and Oxford counties by the University of New Hampshire Survey Center in spring and summer of 2007, using random digit dialing. The total number of interviews was 969 in Coos and 751 in Oxford. Data were weighted to adjust for sampling biases based on size of the household. Data were also weighted to correct for potential sampling biases on the basis of age, sex, or race/ ethnicity by deriving weights from an age/sex/race population profile of the region based on 2006 Census Population Estimates data (a maximum weighting factor was established to avoid unusual cases unduly influencing overall figures). The maximum margin of error (95\% CI) for percentages reported at the county level is $+/-3.2$ percentage points. The maximum margin of error for percentages reported at the sub-county level is +/-5.7 percentage points, though it is substantially lower in most cases. Reported differences between population sub-groups (newcomers/long-timers, income groups, and age groups) are statistically significant at the .10 level. 


\section{Endnotes}

1 US Bureau of Economic Analysis Regional Economic Information System; this is the percentage of all jobs in the county in manufacturing. In 2000, 22 percent of Coos residents worked in the manufacturing sector, down from 28 percent in 1990.

2 US BEA REIS; this is the percentage of total earnings from all establishments located in Coos County. The most recent closures of the Fraser pulp mill in Berlin, the Wasau paper mill in Groveton, and the cutbacks at Fraser's Gorham mill are not reflected in these figures.

3 The 2007 closure of another paper mill in Gilman, VT, just across the Connecticut River from Coos, resulted in the loss of another 115 jobs in the region.

4 US Census Bureau

5 "Newcomers" are defined here as those who moved to the county as adults (versus "long-timers" who did not). Income groups are based on national income quintiles published for the year 2005.

"Low-income" residents were in the bottom quintile, with annual household incomes less than $\$ 20,000$. "Middle-income" residents had household incomes between $\$ 20,000$ and $\$ 90,000$. "Affluent" residents had household incomes above $\$ 90,000$. Coos respondents were broken down by age into three categories: 18-29, 30-49, and over 50 .

${ }^{6}$ Berlin/Gorham had 333 respondents living there. "Lancaster and South" includes the towns of Carroll, Dalton, Jefferson, Lancaster, Randolph, Shelburne, and Whitefield (337 respondents). "Colebrook and North" includes Clarksville, Colebrook, Columbia, Dummer, Erroll, Milan, Northumberland, Pittsburg, Stark, Stewartstown, and Stratford (297). US Route 2 serves as a geographical marker, with towns on or below Route 2 forming the southern region, and towns north of Route 2 (outside Berlin and Gorham) forming the northern region.

7 Concern about crime was much lower in Gorham (30\%) than Berlin, though sample size results in a $95 \%$ confidence interval of $+/-9.3 \%$.

8 This is a conservative estimate based on a preliminary count of only those responses to questions about mothers' and fathers' occupation that explicitly indicated employment in forest-based industries. Other, more generic occupational descriptions that were most likely related to the mills, such as "engineer" or "mechanic," were not counted.

9 The Carsey Institute has also conducted the CERA survey in the Great Plains, Central Appalachia, the Mississippi Delta, the Black Belt in Alabama, the Rocky Mountains, and the Pacific Northwest.

\section{A U T H O R}

Chris R. Colocousis is a Research Associate at the Carsey Institute and a Ph.D. Candidate in the Department of Sociology at the University of New Hampshire (chris. colocousis@unh.edu).

\section{ACKNOW LED GEMEN T S}

The author would like to thank the advisory board of the Neil and Louise Tillotson Fund of the New Hampshire Charitable Foundation for comments on an earlier version of this report. Mil Duncan, Kenneth Johnson, Curt Grimm, and Amy Sterndale at the Carsey Institute, and Richard Ober and Racheal Stuart at the New Hampshire Charitable Foundation provided valuable assistance. UNH Department of Sociology Professor Lawrence Hamilton prepared the survey data for analysis and made thoughtful comments. The collection of the survey data and the preparation of this report were made possible by the Neil and Louise Tillotson Fund of the New Hampshire Charitable Foundation. Responsibility for the analysis lies with the Carsey Institute. 


\section{CARSEY}

Building knowledge for families and communities

The Carsey Institute at the University of New Hampshire conducts independent, interdisciplinary research and communicates its findings to policy makers, practitioners and the general public.

Huddleston Hall

73 Main Street

Durham, NH 03824

(603) $862-2821$

www.carseyinstitute.unh.edu

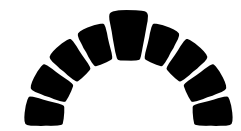

NEW HAMPSHIRE CHARITABLE FOUNDATION

The New Hampshire Charitable Foundation, founded in 1962, manages a collection of charitable funds, totaling nearly $\$ 490$ million, created by individuals, families and corporations. The Foundation awarded more than $\$ 33$ million in grants, scholarships and initiatives last year; more than $\$ 125$ million in just the past five years.

37 Pleasant Street

Concord, $\mathrm{NH} 03301$

(603) 225-6641

www.nhcf.org 